\title{
ANALISIS NARASI TZVETAN TODOROV PADA FILM SOKOLA RIMBA
}

\author{
Siti Shadrina Azizaty ${ }^{1}$, Idola Perdini Putri ${ }^{1}$ \\ ${ }^{1}$ Universitas Telkom
}

\begin{abstract}
ABSTRAK
Film merupakan media penyampaian informasi yang mudah dan cepat untuk diterima oleh masyarakat. Di Indonesia, banyak film yang mengangkat permasalahan kehidupan sosial yang ada pada masyarakat Indonesia ke layar lebar untuk memberikan informasi, hiburan, dan edukasi. Film tidak hanya berasal dari hasil karya penulis skenario atau sutradara, namun juga dapat berasal dari buku ataupun kisah nyata yang pernah terjadi sehingga dapat divisualisasikan ke dalam film yang berisikan skenario adaptasi. Film yang diangkat berdasarkan kisah nyata dan diadaptasi untuk diceritakan kembali memiliki penyesuaian yang akan mempengaruhi unsur naratif sebagai unsur pembentuk film yang berkaitan dengan aspek cerita, tokoh, masalah, waktu, lokasi dan lainnya. Salah satunya film Sokola Rimba yang berdasarkan kisah nyata Butet Manurung yang memberikan pendidikan untuk orang rimba di hutan Bukit Dua Belas, Jambi yang sebelumnya telah ditulis dalam buku. Penelitian ini membahas struktur narasi pada film untuk mengetahui bagaimana struktur naratif dari tahap awal hingga akhir film meliputi equilibrium, disruption, recognition disruption, attempt to repair the disruption, dan reinstatement of the equilibrium dengan menggunakan metode penelitian kualitatif dan analisis naratif Tzvetan Todorov dengan pendekatan Nick Lacey dan Gillespie. Hasil penelitian yang diperoleh, film Sokola Rimba ini menggunakan alur yang lebih modern dan tidak terpaku dengan alur tradisional yang dijabarkan oleh Tzvetan Todorov karena terdapat pengulangan disruption, recognition disruption, dan attempt to repair the disruption. Selain itu, unsur mise en scene mendukung naratif dalam membangun suasana pada film.
\end{abstract}

Kata-kata Kunci: Film, Analisis Naratif, Struktur Naratif, Tzvetan Todorov, Biografi.

\section{NARRATIVE ANALYSIS OF TZVETAN TODOROV ON SOKOLA RIMBA FILM}

\begin{abstract}
Film is one of a mass communication media to deliver message easily and quickly to public through the audio-visual. In Indonesia, there are many films that raise the issue of social life within Indonesian society into big screen to provide information, entertainments, and education. A Film is derived from the work of scriptwriter or director, but it can also come from a book. The story of a book can be visualized into a film that contains adaptation of scenarios.The film which based on the true story and adapted to be retold certainly have an adjustment that will affect the narrative as a film-forming elements which relates with aspect of the story, characters, problems, times, locations, etc. One of the film that adapted from a book is the Sokola Rimba film based on the true story of Butet Manurung, a young women who fight to provides education for the isloated children in Bukit Dua Belas forest, Jambi. This research aims to determine how narrative structure from beginning until the end of film comprehends equilibrium, disruption, recognition disruption, attempt to repair the disruption, and reinstatement of the equilibrium using qualitative research method and narrative analysis of Tzvetan Todorov with Nick Lacey and Gillespie approach. The result obtained Sokola Rimba Film uses more modern plot, because there are repetition of disruption, recognition disruption, and attempt to repair the disruption. Other than that, there are elements of the mise en scene that supports the narrative to creating atmosphere in the film.
\end{abstract}

Keywords: Film, Narrative Analysis, Narrative Structure, Tzvetan Todorov, Biography.

Korespondensi: Siti Shadrina Azizaty. Universitas Telkom, Jl. Telekomunikasi, Sukapura, Dayeuhkolot, Bandung 40257.Email: shadrinatsha@gmail.com 


\section{PENDAHULUAN}

Film merupakan media penyampaian informasi yang mudah dan cepat untuk diterima oleh masyarakat. Film sendiri merupakan salah satu dari media komunikasi massa yang menyampaikan pesan kepada masyarakat luas dengan mudah dan cepat melalui audio visual. Komunikasi dan manusia merupakan dua hal yang tidak dapat di pisahkan dari kehidupan sebagai makhluk sosial (Yasundari, 2016: 208). Di Indonesia, seiring dengan perkembangannya banyak film yang mengangkat permasalahan kehidupan sosial yang ada pada masyarakat Indonesia ke layar lebar untuk memberikan informasi, hiburan, dan edukasi. Cerita dikemas sedemikian rupa agar sesuai dengan apa yang terjadi dan meyakinkan penonton melalui berbagai unsur, mulai dari jalan cerita, permasalahan, lokasi, waktu, tata rias, kostum, bahkan akting atau pergerakan pemain. Ada beberapa film yang mengangkat permasalahan kehidupan sosial di masyarakat Indonesia, seperti film Di Timur Matahari (2012), Tanah Surga Katanya (2012), Laskar Pelangi (2008), Atambua $39^{\circ}$ Celsius (2012), dan Sokola Rimba (2013).

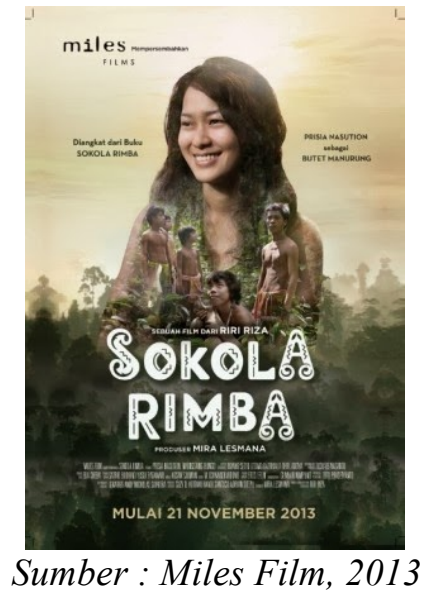

Gambar 1 Poster Film Sokola Rimba
Film tidak hanya berasal dari hasil karya penulis skenario atau sutradara, namun juga dapat berasal dari buku ataupun kisah nyata yang pernah terjadi sehingga kisah tersebut dapat divisualisasikan ke dalam film yang tentunya berisikan skenario adaptasi dari kisah tersebut. Adaptasi bisa dibilang adalah salah satu cara yang paling mudah untuk membuat film laris (Jusuf, 2017). Hal tersebut dikarenakan masyarakat sudah tidak asing dengan cerita yang akan disuguhkan. Salah satu film yang diadaptasi dari sebuah buku yang menceritakan tentang permasalahan sosial yang terjadi di Indonesia adalah film Sokola Rimba karya Riri Riza. Namun, film ini tidak memiliki penonton yang banyak seperti film biopik adaptasi lainnya seperti film Habibie \& Ainun yang menembus jutaan penonton ataupun film Soekarno: Indonesia Merdeka yang rilis di tahun yang sama dengan jumlah penonton sebesar 960.071. Film Sokola Rimba bahkan tidak masuk dalam daftar 15 peringkat teratas perolehan penonton di tahun 2013 (Film Indonesia, 2013).

Film ini diadaptasi dari kisah nyata Butet Manurung yang membangun sekolah untuk masyarakat pedalaman di Hutan Bukit Dua Belas, Jambi. Selain itu, mengkisahkan tentang perjuangan orang rimba yang mempertahankan hutan dan alam sekitar sebagai rumah mereka serta larangan memperoleh pendidikan yang dapat melanggar adat istiadat. Film yang disutradarai oleh Riri Riza ini merupakan film bergenre biografi - 
drama yang berisikan skenario adaptasi dari sebuah kisah yang telah ada. Menurut Dwight V Swain dan Joye R Swain terdapat tiga strategi untuk mengadaptasi cerita dari novel ke film, yaitu mengikuti buku yang menekankan pada totalitas pengubahan dari novel ke film dengan asumsi menjadi representasi, mengambil konflik-konflik pentingnya saja yang fokus pada persoalan - persoalan yang menonjol dan dapat dikembangkan sesuai konteksnya, atau membuat cerita baru yang menekankan pada kreativitas kreator film, sehingga novel hanya sebagai bahan dasar untuk dikreasikan dengan optimal (Simbolon, 2004, dalam Saputra, 2009: 46).

Film ini rilis enam tahun setelah pengalaman Butet Manurung diterbitkan dalam buku, di tahun 2007, dengan judul Sokola Rimba. Banyak hal yang harus diperhatikan atau disesuaikan untuk memvisualisasikan cerita dari sebuah buku, mulai dari tokoh, lokasi, bahasa, serta permasalahan yang ada untuk diceritakan ulang ke dalam film. Hal - hal tersebut merupakan unsur - unsur yang membentuk film yang dapat mempengaruhi konten film itu sendiri. Film memiliki dua unsur pembentuk yaitu unsur naratif dan unsur sinematik yang saling berinteraksi dan berhubungan untuk membentuk suatu film (Pratista, 2008: 1).

Unsur naratif dalam film berkaitan dengan aspek cerita yang memiliki unsur tokoh, lokasi, masalah, waktu, dan lainnya yang akan membentuk sebuah kronologis peristiwa yang memiliki tujuan. Cerita merupakan bagian dari sebuah narasi. Narasi berasal dari kata Latin narre, yang artinya "membuat tahu". Dengan demikian, narasi berkaitan dengan upaya untuk memberitahu sesuatu atau peristiwa (Eriyanto, 2013: 1). Tidak hanya cerita, plot juga merupakan bagian dari narasi. Cerita merupakan urutan kronologis suatu peristiwa, dimana peristiwa itu dapat ditampilkan dalam teks dan bisa juga tidak ditampilkan dalam teks. Sedangkan plot adalah apa yang ditampilkan secara eksplisit dalam sebuah teks (Eriyanto, 2013: 16).

Dalam narasi, peristiwa terdiri atas berbagai bagian. Narasi tidak identik dengan peristiwa aktual yang sebenarnya, karena pembuat narasi bukan hanya memilih peristiwa yang dipandang penting tetapi juga menyusun peristiwa tersebut ke dalam babak atau tahapan tertentu. Peristiwa dilihat mempunyai tahapan, mempunyai awal dan akhir. Dalam peristiwa sesungguhnya, tahapan itu tidaklah selalu ditemukan (Eriyanto, 2013: 45).

Hal tersebut membuat peneliti tertarik untuk meneliti film Sokola Rimba dari segi unsur naratifnya atau penyusunan peristiwa yang diangkat dari sebuah novel. Peneliti menggunakan analisis naratif yang berfungsi untuk memahami dan mengetahui struktur pada suatu cerita. Teori dasar yang digunakan peneliti adalah teori struktur naratif Tzvetan Todorov karena sangat cocok digunakan untuk meneliti film - film yang bergenre drama seperti film Sokola Rimba. Menurut Todorov, suatu narasi mempunyai struktur dari awal hingga akhir, dan mempunyai urutan kronologis, motif dan plot, dan hubungan sebab akibat suatu peristiwa (Eriyanto, 2013: 46). Struktur narasi 
Todorov terdapat 3 bagian yaitu awal (equilibrium), tengah (gangguan), dan akhir (equilibrium). Namun, Nick Lacey dan Gillespie memodifikasi struktur tersebut menjadi lima bagian, yaitu equilibrium yang merupakan keseimbangan situasi, disruption yang merupakan gangguan terhadap keseimbangan, recognition disruption yang merupakan kesadaran terjadinya gangguan, attempt to repair the disruption yang merupakan usaha untuk memperbaiki gangguan, dan reinstatement of the equilibrium yang merupakan pemulihan menuju keseimbangan (Eriyanto, 2013: 47). Peneliti akan menggunakan struktur narasi Tzvetan Todorov yang di modifikasi oleh Nick Lacey dan Gillespie untuk melihat bagaimana struktur narasi yang ada pada film ini.

Berdasarkan latar belakang masalah tersebut, fokus penelitian peneliti adalah bagaimana struktur naratif pada film Sokola Rimba dengan menggunakan teori Struktur Narasi Tzvetan Todorov dengan pendekatan Nick Lacey dan Gillespie. Rumusan masalah pada penelitian ini adalah (1) Bagaimana equilibrium atau kondisi keseimbangan pada film Sokola Rimba? (2) Bagaimana disruption atau gangguan terhadap keseimbangan pada film Sokola Rimba? (3) Bagaimana recognition disruption atau kesadaran terjadinya gangguan pada film Sokola Rimba? (4) Bagaimana attempt to repair the disruption atau usaha untuk memperbaiki gangguan pada film Sokola Rimba? (5) Bagaimana reinstatement of the equilibrium atau pemulihan menuju keseimbangan atau keadaan awal pada film Sokola Rimba?

\section{METODE PENELITIAN}

Dalam penelitian ini, metode penelitian yang digunakan adalah metode penelitian kualitatif naratif. Metode penelitian adalah prosedur atau cara dalam melakukan penelitian untuk menjawab tujuan penelitian (Ghony \& Almanshur, 2012: 3). Metode penelitian kualitatif merupakan metode penelitian naturalistik karena penilaiannya dilakukan pada kondisi yang alamiah (natural setting) (Sugiyono, 2016: 8). Penelitian dilakukan pada obyek alamiah, dimana obyek tersebut dapat berkembang apa adanya dan tidak dimanipulasi oleh peneliti. Kehadiran peneliti tidak memiliki pengaruh terhadap dinamika obyek tersebut.

Jenis penelitian yang digunakan adalah analisis naratif dengan teori struktur narasi Tzvetan Todorov. Analisis naratif dipakai untuk mengkaji struktur cerita dari narasi fiksi seperti novel ataupun film. Selain itu, analisis naratif menempatkan teks sebagai sebuah cerita baik itu fiksi seperti novel, puisi, dongeng, film, komik, ataupun fakta seperti berita. Teks tersebut merupakan rangkaian peristiwa, logika, tata urutan peristiwa, dan bagian dari peristiwa yang dipilih dan dibuang (Eriyanto, 2013: 9).

Objek penelitian dalam penelitian ini adalah film Sokola Rimba yang telah rilis pada 21 November 2013 lalu. Bagian dari objek yang diteliti adalah narasi atau alur cerita yang ada pada film Sokola Rimba yang berdurasi 90 menit. Teknik pengumpulan data dilakukan 
dengan mengobservasi film untuk mencari rumusan permasalahan yang akan dijawab, mengumpulkan data - data dari literatur ataupun artikel online, serta melakukan wawancara untuk triangulasi data atau keabsahan data.

Analisis data merupakan proses mencari dan menyusun data yang diperoleh dari hasil penelitian secara sistematis (Sugiyono, 2016: 244). Data yang telah diperoleh akan dianalisis untuk menjawab rumusan masalah yang ada. Pada penelitian ini, data yang ada baik data primer dan data sekunder akan di analisis dengan menggunakan teknik analisis naratif Tzvetan Todorov. Film Sokola Rimba yang menjadi obyek penelitian akan diobservasi dan kemudian akan dicatat secara teliti serta memilih hal - hal pokok yang mewakili dari lima poin struktur narasi Tzvetan Todorov yang di modifikasi oleh Nick Lacey dan Gillespie. Setelah itu, data akan di analisis sesuai struktur narasi tersebut untuk mengetahui bagaimana alur cerita atau kronologis peristiwa yang ditampilkan dalam film Sokola Rimba. Selanjutnya data disajikan dalam bentuk uraian singkat, bagan, ataupun grafik. Penyajian data bersifat naratif agar data mudah dipahami. Langkah selanjutnya adalah penarikan kesimpulan dan verifikasi serta pemeriksaan keabsahan data dengan mewawancarai ahli atau sutradara sekaligus penulis skenario dari film yang diteliti.

Lokasi penelitian dapat dilakukan dimana saja karena fokus penelitian analisis naratif tidak terkait dengan tempat penelitian. Waktu penelitian dilaksanakan oleh peneliti selama bulan September 2016 hingga bulan Mei 2017.

\section{HASIL DAN PEMBAHASAN}

Pada tahap ini, peneliti membagi film yang berdurasi 90 menit ini menjadi beberapa potongan story atau cerita, baik satu sequence ataupun lebih, yang mewakili beberapa tahapan dalam struktur narasi. Dalam menjelaskan hasil penelitian, peneliti didukung oleh data sekunder berupa buku, artikel, video behind the scene film dan juga wawancara ahli. Dari keseluruhan film, peneliti mengelompokkan 24 story atau bagian berdasarkan cerita yang mewakili tahapan - tahapan yang ada dari menit 00.19 hingga 01.27 .15

Pada story ke empat di menit 07.45 09.45 merupakan tahap equilibrium atau keseimbangan dimana Nengkabau dan Beindah, bercengkrama dengan ibu guru mengenai mereka yang memiliki keinginan untuk menahan orang - orang yang menebang kayu dengan jumlah banyak ketika mereka sudah pintar, sebelum akhirnya ibu guru kembali mengajar matematika kepada mereka. Salah satu anak murid bernama Menosur, yang juga berada di saung, melihat sosok anak laki - laki mengamati mereka yang sedang belajar. Menosur berjalan mendekati anak tersebut, namun anak tersebut pergi. Menosur bertemu dengan anak laki - laki itu di tengah hutan. Ibu guru Butet, Beindah, dan Nengkabau datang mendekati Menosur dan anak laki - laki tersebut. Melihat hal itu, anak laki - laki itu langsung menyembunyikan gulungan kertas yang ia bawa. Butet menanyakan identitas anak 
laki-laki tersebut. Anak tersebut memperkenalkan diri bahwa ia bernama Nyungsang Bungo dari Mekakal Hilir dan nama Tumenggungnya adalah Belaman Badai. Setelah memperkenalkan diri, Bungo langsung berlari pergi.

Dalam percakapan yang dilakukan antar tokoh bahasa yang digunakan adalah bahasa rimba. Ini menunjukkan adanya komunikasi antarbudaya yang terjadi pada film antara orang rimba dengan Butet atau orang luar yang bukan berasal dari rimba. Komunikasi antarbudaya merupakan proses pertukaran pikiran dan makna antara orang-orang yang berbeda budaya (Heryadi dan Silvana, 2013: 97). Namun, terdapat subtitle yang membantu peneliti dalam memahami dialog yang dilakukan. Pada saat Menosur melihat memperhatikan anak laki laki dari kejauhan, terdapat unsur non-diegetic sound berupa backsound yang memiliki nada tinggi. Unsur diegetic sound berupa suara burung dan jangkrik mengiringi story ke empat ini. Pada menit ke 09.40, unsur non-diegetic berupa backsound mengiringi kepergian Bungo setelah memperkenalkan diri.

Pada story ketujuh di menit 15.56 18.25, merupakan tahap disruption atau munculnya suatu gangguan terhadap keseimbangan. Dalam tahap ini, rasa penasaran Butet semakin besar ketika melihat peta Kawasan Taman Nasional Bukit 12 untuk melihat jarak tempuh yang dilalui oleh Bungo dari hilir menuju hulu. Keesokan harinya di kantor, Butet melihat kesempatan untuk dirinya bisa pergi ke hilir. Bahar yang pergi ke kantor
Kabupaten membuat Butet dengan mudah untuk meminta dana kepada Gustav. Gustav memberikan uang untuk keperluan Butet pergi ke hilir. Butet membeli perlengkapan perjalanannya yang dibutuhkan di pasar dan bertemu dengan Nengkabau dan Beindah yang ingin ikut bersamanya ke Hilir Makekal.

Unsur non-diegetic sound, yaitu voiceover muncul pada adegan ini yang menjelaskan rasa penasaran Butet. Dialog yang terjadi ketika Butet berada di kantor menggunakan bahasa Indonesia, namun ketika Butet berinteraksi atau berbicara dengan orang rimba, dialog menggunakan bahasa rimba sehingga terdapat subtitle yang memudahkan peneliti untuk memahami dialog. Unsur non-diegetic pada story ini tidak hanya voice-over, namun terdapat backsound dengan tempo lambat terjadi di awal ketika Butet mengamati peta Kawasan Taman Nasional Bukit Duabelas, dan Butet pergi ke pasar untuk membeli perlengkapan masuk ke hutan. Backsound yang ceria megiringi adegan Nengkabau dan Beindah memaksa Butet untuk membuka pintu mobil.

Pada story ke empat belas di menit 39.15 - 42.52, merupakan tahap Recognition Disruption dimana konflik mencapai puncak atau klimaks. Tumenggung datang menghampiri Butet untuk mengusirnya secara halus. Ekspresi Butet sedih saat mendengar kabar tersebut. Tumenggung meyakinkan Butet bahwa ia tidak mungkin mengajar di rombong tersebut karena banyak anggota rombong yang percaya bahwa pensil dapat membawa penyakit dan menyebabkan terjadinya perselisihan. Butet 
kemudian pergi dari rombong tersebut bersama Nengkabau dan Beindah. Pada saat Butet diusir, Nyungsang Bungo sedang berburu bersama teman - temannya. Ketika Bungo pulang dan menyadari Butet pergi, ia sangat marah dan kesal. Ia ingin belajar kepada Butet karena tidak mau dibodohi oleh orang luar. Bungo berlari berusaha mengejar Butet, namun usahanya gagal. Ilustrasi musik yang bertempo lambat mengiringi adegan dimana Bungo marah karena ia ingin belajar dengan Butet hingga ia berusaha untuk mengejar Butet. Dialog yang terjadi pada story ini menggunakan bahasa rimba, sehingga terdapat subtitle yang membantu penonton atau peneliti dalam memahami adegan yang ada.

Pada story ke enam belas di menit 49.00 -53.56, merupakan tahap attempt to repair the disruption atau penyelesaian permasalahan. Butet pergi ke kawasan transmigran di pinggiran hutan antara hulu dan hilir untuk bertemu dengan ibu Pariyan yang berasal dari Jawa Tengah. Butet bercerita mengenai pengalamannya mengajar di rombong Belaman Badai yang tidak berjalan dengan baik dan belum mendapatkan cara untuk kembali masuk ke rombong tersebut. Mendengar cerita tersebut, ibu Pariyan memberitahu Butet bahwa rombong Tumenggung Belaman Badai sering datang kerumahnya untuk menjual damar atau karet setiap minggu. Butet terkejut dan mendapatkan ide untuk mengajar di rumah ibu Pariyan. Butet yang mendapatkan izin dari ibu Pariyan untuk mengajar dirumahnya langsung menyebarkan informasi kepada orang - orang rimba bahwa kini ia mengajar dirumah bu Pariyan. Setelah menyebarkan informasi tersebut, Butet mulai mengajar anak - anak rimba di rumah bu Pariyan, termasuk Nengkabau dan Beindah.

Terdapat unsur non-diegetic berupa voice-over yang menjelaskan mengenai Taman Nasional yang dikepung oleh perkebunan kelapa sawit dari para transmigran yang datang sejak tahun 80an. Unsur non-diegetic lainnya adalah backsound atau ilustrasi musik yang gembira ketika Butet melewati perkebunan kelapa sawit dan menuju rumah ibu Pariyan dan ilustrasi musik yang ceria pada saat Butet menyebarkan informasi agar dapat kembali mengajar Bungo. Musik yang ceria dapat membuat mood penonton menjadi lebih semangat (Pratista, 2008: 155). Terdapat upaya dalam menyelesaikan permasalahan yang ada, yaitu Butet berinisiatif untuk mengajar di rumah ibu Pariyan agar Bungo tetap dapat belajar. Dialog yang digunakan dalam story ini antara Butet dengan Ibu Pariyan adalah bahasa Indonesia, sehingga tidak ada subtitle pada dialog tersebut.

Pada story ke 24 di menit ke 01.23.18 01.27.15, merupakan tahap reinstatement of the equilibrium atau tahap dimana muncul keseimbangan yang baru. Butet yang dipecat oleh Bahar kembali ke Jambi beberapa bulan kemudian untuk membangun Sokola Rimba. Ia tidak mengira bahwa teman - temannya di Wanaraya banyak yang mendukung keinginan dirinya untuk kembali mengajar anak - anak rimba. Butet, Andit, Gustav, dan teman - teman lainnya masuk ke dalam hutan dan bertemu dengan rombong Belaman Badai. Mereka sedang berdiskusi dengan pihak perkebunan 
kelapa sawit mengenai perluasan tanah yang ada. Namun, Bungo yang ikut dalam pembicaraan tersebut memilih untuk membaca surat perjanjian tersebut agar seluruh anggota rombongnya mengetahui isi perjanjian tersebut. Beberapa poin yang merugikan mereka dapat ditolak dan tidak sembarangan memberikan cap jempol yang merupakan tanda persetujuan. Bungo membaca isi perjanjian tersebut dengan keras. Para kelompok kepentingan perkebunan terkejut. Di sisi lain, Butet dan teman temannya terharu melihat Bungo yang lancar membaca dan bisa menghadapi orang luar yang ingin mengambil wilayah mereka. Melihat Bungo yang seperti itu membuat Butet mengingat sikap yang tepat dalam menghadapi perubahan, yaitu dengan menjadikan pengetahuan sebagai senjata beradaptasi.

Terdapat unsur non-diegetic sound berupa voice-over yang menjelaskan keterkejutan Butet bahwa ternyata banyak temannya yang mendukungnya. Unsur nondiegetic ketika Bungo membacakan surat perjanjian tersebut, adalah voice-over Butet yang menjelaskan sikap Bungo dalam menghadapi perubahan. Unsur non-diegetic berupa ilustrasi musik yang mendayu - dayu dengan iringan biola dan drum yang ceria membuat mood bahagia dan enerjik. Selain itu, terdapat voice-over Butet yang menjelaskan bahwa ia mendapatkan banyak pelajaran dari rimba. Ending atau akhir dari film ini adalah para pendiri Sokola Rimba dan beberapa anak rimba berfoto bersama dan muncul foto lama dari para pendiri Sokola Rimba yang asli dengan gaya foto yang sama. Hal ini merupakan penggalan kisah nyata yang dihadirkan dalam film biografi.

Dari keseluruhan film, dialog yang digunakan ketika berinteraksi dengan orang rimba ataupun sesama orang rimba adalah bahasa rimba. Ini membuat film Sokola Rimba menjadi unik dan memberikan pengetahuan lebih kepada penonton mengenai keragaman budaya yang dimiliki oleh Indonesia. Seperti yang dikatakan oleh Riri Riza selaku sutradara dan penulis skenario bahwa ia ingin membuat film yang memiliki rasa otentiknya. Film dapat menciptakan penceritaan yang otentik sehingga tidak terasa jauh dan berjarak. Film juga merupakan bagian dari keinginan besar beliau untuk mendokumentasikan keragaman bahasa dan budaya Indonesia melalui film populer (Wawancara Online, 5 April 2017). Namun, pada saat terjadi dialog terdapat subtitle yang mempermudah penonton ataupun peneliti dalam memahami dialog.

Selain itu, terdapat unsur mise en scene yang membantu naratif yang ada pada film. Mise en scene adalah unsur sinematik yang paling mudah kita kenali karena hampir seluruh gambar yang kita lihat dalam film adalah bagian dari unsur ini (Pratista, 2008: 61). Dengan kata lain, mise en scene merupakan segala aspek yang dapat dilihat pada saat sebuah film yang sedang diproyeksikan dalam suatu layar. Unsur - unsur ini dapat mendukung naratif dan membangun suasana dalam sebuah film. Dalam film Sokola Rimba, terdapat unsur mise en scene yang mendukung naratif pada film itu 
sendiri. Mise en scene memiliki 4 unsur, yaitu setting, kostum atau make up, pencahayaan, dan pemain serta pergerakannya atau akting. Peneliti hanya meneliti unsur setting, kostum atau make up, dan pemain dan pergerakannya dalam film ini karena unsur tersebut lebih menonjol dalam mendukung naratif yang ada.

Dari keseluruhan film, setting film Sokola Rimba adalah shot on location dimana film diproduksi di lokasi aktual yang sesungguhnya atau lokasi yang mirip ataupun mendekati lokasi cerita sesungguhnya, yaitu Taman Nasional Bukit Dua Belas di Jambi dan Jakarta. Berdasarkan fungsinya, lokasi yang diambil tersebut untuk meyakinkan penonton bahwa seluruh peristiwa dalam film terjadi di lokasi cerita sesungguhnya dan sesuai dengan konteks cerita. Menurut Mira Lesmana dalam video Di Balik Layar Film Sokola Rimba Bagian 3 pada menit 01.55, tidak mungkin membawa orang - orang rimba keluar dari lokasi yang sebenarnya karena beliau ingin menceritakan tentang kehidupan mereka, sehingga beliau dan tim harus berada di dalam hutan. Selain itu, setting tersebut dapat memberikan informasi waktu yang sesuai dengan konteks naratifnya. Setting berfungsi untuk memberikan informasi kapan cerita dalam film berlangsung. Film Sokola Rimba merupakan film periodik yang mengangkat kisah sekitar tahun 2001an, sehingga setting harus disesuaikan dengan keadaan pada tahun tersebut. Contohnya seperti kendaraan bermotor yang dipakai pada tahun itu, penggunaan papan tulis hitam dengan kapur, bahkan kondisi politik di Indonesia saat Gus Dur lengser yang ada pada menit 13.20 yang disiarkan melalui berita di televisi.

Setting juga dapat menjadi penunjuk status sosial pelaku cerita pada film ini. Untuk orang luar (bukan orang rimba) setting lebih beraneka ragam daripada orang rimba, seperti rumah tapak, kendaraan, komputer, dan buku misalnya. Sedangkan orang rimba hanya memiliki setting yang apa adanya layaknya di dalam hutan, seperti pondok atau saung dan peralatan berburu tradisional. Setting juga berhubungan dalam membangun mood atau suasana dalam film. Suasana setting berkaitan dengan tata cahaya. Dalam film ini, ketika settingnya terang, suasana yang tercipta lebih formal dan akrab. Contohnya ketika Butet ngobrol bersama Andit atau anak - anak rimba di warung saat menyebarkan informasi belajar di rumah ibu Pariyan. Namun, ketika settingnya gelap, suasana yang tercipta menjadi dingin, mencekam, dan penuh misteri. Contohnya saat Butet harus bermalam di hutan dan saat ia berselisih dengan Bahar di kantor. Selain itu, ketika Bungo menyendiri setelah mendapatkan kabar bahwa Tumenggung Belaman Badai meninggal dunia, cuaca mendung dan hujan yang turun merupakan salah satu cara untuk membangun mood atau suasana duka atau haru. Cuaca mendung atau hujan merupakan elemen natural yang digunakan untuk membangun mood dalam film ini.

Untuk kostum dan make up atau tata rias dalam film tidak hanya sebagai busana, tetapi memiliki fungsi yang sesuai dengan naratifnya. Kostum juga dapat menjadi penunjuk ruang dan waktu (Prastista, 2008: 71). Pakaian yang santai 
dipakai oleh Butet karena untuk menyesuaikan dengan lokasinya berkegiatan atau bekerja. Ketika ia sedang di hutan dan mengajar anak anak, pakaian yang digunakan adalah pakaian santai seperti kaos, ketika ia berada di kantor maka memakai kemeja, ketika ia bertemu dengan pendonor dan menjadi pembicara di seminar pakaian yang dipakai lebih sopan dan formal. Kostum juga dapat menjadi penunjuk status sosial tokoh. Orang luar memakai pakaian yang lebih tertutup daripada orang rimba karena mereka dapat dikatakan lebih maju dan modern. Sedangkan orang rimba menggunakan kain hanya untuk menutup bagian vitalnya saja baik untuk laki - laki maupun perempuan dan tidak memakai aksesoris yang beragam. Sebenarnya, perempuan rimba tidak menggunakan penutup dibagian dada dan tidak boleh diambil gambarnya. Namun sudah mendapatkan perizinan melalui keluarga dan Tumenggung. Hal ini diungkap Mira Lesmana selaku produser dari film ini dalam wawancara di Balik Layar Bagian 2 pada menit 00.17 hingga 01.36. Sedangkan orang luar memakai kostum yang lebih dinamis, seperti menggunakan kalung, anting, gelang, jam tangan, sepatu, dan lain sebagainya. Tetapi, bagi orang rimba yang sudah dapat menerima dan berinteraksi dengan orang luar, seperti Nengkabau dan Beindah, mereka menggunakan kaos untuk atasan dengan kain penutup sebagai celana ketika keluar dari hutan dan berinteraksi dengan orang luar. Kostum juga mempengaruhi image atau citra dari tokoh dalam film Sokola Rimba ini. Kostum orang rimba yang hanya menutup bagian vital merupakan image yang ada pada mereka. Untuk make up, dalam film ini juga digunakan untuk menyamakan pemain dengan wajah asli tokoh yang diperankan. Film ini adalah film biografi dari kisah nyata Butet Manurung, sehingga Prisia Nasution yang memerankan tokoh Butet Manurung dirias agar mirip dengan Butet Manurung.

Pergerakan pemain dalam mise en scene sangat penting untuk naratif yang ada. Terdapat beberapa jenis karakter atau pelaku cerita, yaitu karakter manusia, karakter nonmanusia, karakter nonfisik, dan karakter animasi. Film ini menggunakan karakter manusia dan karakter animasi dimana manusia digunakan sebagai pelaku atau tokoh cerita utama dan animasi dua dimensi yang mampu menghidupkan karakter manusia, hewan, ataupun monster yang dapat mendukung cerita dari film, seperti saat adegan Bungo menceritakan tentang pemanjat pohon madu kepada Butet dan teman - temannya. Film ini mengkombinasi karakter nyata dan animasi agar lebih meyakinkan dan mempermudah penonton dalam memahami cerita film. Di lihat dari jenis pemainnya, film Sokola Rimba menggunakan pemain figuran, aktor amatir, dan juga aktor profesional. Pemain figuran dalam film ini digunakan pada adegan yang bersifat masal seperti di pasar dan terminal. Selain itu, pemain figuran merupakan karakter di luar para tokoh dan pelaku cerita utama, seperti karyawan yang ada di Wanaraya, wartawan yang bertemu dengan bahar, serta peserta seminar. Aktor amatir pada film ini adalah orang - orang rimba itu sendiri. Mereka digunakan bukan karena 
kemampuan akting yang dimiliki, namun karena otentitas yang dimiliki oleh mereka dengan karakter yang diperankan. Seperti yang dikatakan oleh Riri Riza berikut ini :

"Keputusan yang didasarkan pada keinginan membuat sesuatu yang lebih otentik dan segar. Saya ingin menjadikan orang rimba sebagai bagian dari 'cerita pembuatan film' ini. Hingga menjadi kebanggaan mereka suatu hari nanti. Tentu ada resikonya, namun membayangkan membawa aktor masuk ke rimba untuk berakting sama saja beresiko juga." (Wawancara Online, 5 April 2017)

Riri Riza menjelaskan dalam wawancara Di Balik Layar Film Sokola Rimba Bagian 3 pada menit ke 01.25 tentang orang rimba yang ikut memerankan karakter dalam film ini. Riri Riza dan Butet Manurung percaya bahwa orang rimba dapat memerankan diri mereka sendiri dan menceritakan kisah ini secara lebih dekat dan sensitif karena mereka mengalami sendiri. Menurut Mira Lesmana pada menit ke 02.17 , tidak mungkin bisa real jika mereka membawa orang kota atau orang dari daerah lain untuk memerankan orang rimba dengan gaya pakaian dan gaya hidup orang rimba, karena kredibilitasnya tidak ada.

Dengan menggunakan orang rimba asli mungkin masih ada beberapa yang masih terlihat kaku ketika di depan kamera. Namun, mereka lebih dapat memahami peran dan juga budaya ataupun adat yang ada. Contohnya untuk kegiatan memanjat pohon madu yang penuh dengan ritual dan mantera, serta kepercayaan mereka yang menganggap pensil dapat membawa penyakit merupakan suatu hal yang sangat dekat dengan mereka karena merekalah yang mengalaminya. Sedangkan untuk aktor profesional dalam film ini adalah mereka yang sudah terlatih dan mampu untuk memainkan segala jenis peran yang diberikan. Dalam film Sokola Rimba, aktor tersebut adalah Prisia Nasution yang memerankan Butet Manurung, Rukman Rosadi sebagai Bahar, Nadhira Suryadi sebagai Andit, Ines Somellera sebagai dr. Astrid Hilde, dan Netta KD sebagai Ibu Pariyan.

Dari kelima alur yang telah di analisis dan dikelompokkan tersebut, peneliti menemukan bagaimana titik alur equilibrium, disruption, recognition to disruption, attempt to repair the disruption, dan reinstatement of the equilibrium yang ada pada film Sokola Rimba ini. Pada tahap equilibrium, cerita diawali dengan situasi normal, teratur, dan tidak ada gangguan. Situasi normal pada film ini terletak pada story 1 hingga story 6 atau dari dari menit ke 00.19 - 15.55. Pada tahap ini, belum ada tindakan tokoh yang membuat kekacauan dan masih berupa pengenalan situasi yang ada dengan diawali oleh keadaan Butet yang mengajar di pedalaman. Pada tahap ini, Butet masuk ke hutan untuk mengajar dan ia bertemu dengan Nyungsang Bungo, anak dari Hilir Makekal yang menyelamatkannya saat ia pingsan di hutan. Walaupun ada sedikit ketegangan pada tahap ini, tidak ada tindakan jahat yang merusak keseimbangan.

Tahap disruption merupakan tahap dimana muncul gangguan yang dapat berupa 
PADA FILM SOKOLA RIMBA

tindakan atau tokoh yang merusak untuk dapat masuk dan Butet mengajar anak keseimbangan, dimana gangguan dari tindakan tokoh yang merusak keseimbangan terletak pada menit 15.56 hingga 31.34 atau pada story 7 hingga story 10. Pada story ke tujuh, rasa penasaran yang dimiliki oleh Butet mendorong dirinya untuk pergi ke Hilir Makekal secara diam - diam tanpa izin Bahar, selaku atasannya. Ia mengambil kesempatan untuk pergi ke Hilir Makekal ketika Bahar sedang pergi ke kantor Kabupaten. Ini mengubah kondisi dimana yang seharusnya Butet hanya mengajar di Hulu Makekal, menjadi melakukan perjalanan jauh untuk bertemu dengan rombong Tumenggung Belaman Badai. Ia merasa ada sesuatu yang di inginkan oleh Bungo terhadapnya setelah mengetahui Bungo sering mengamati dirinya mengajar dari jauh. Butet ditemani oleh Beindah dan Nengkabau menuju Hilir Makekal.

Gangguan yang terjadi pada tahap ini cukup dinamis. Selain Butet yang pergi diam diam, gangguan juga terletak pada story delapan di menit 18.26 hingga 22.12 ketika mereka hampir tertangkap dan tertembak oleh para pembalak liar. Ini dikarenakan Nengkabau memotret para pembalak liar yang ingin menebang pohon. Mereka berlari berusaha menyelamatkan diri. Ketika mereka sudah sampai di rombong Tumenggung Belaman Badai dalam story ke sepuluh, mereka juga harus menunggu izin dari Tumenggung Belaman Badai untuk bisa masuk ke wilayah mereka semalaman. Mereka baru mendapatkan jawaban keesokan paginya dari Tumenggung anak di rombong tersebut.

Tahap recognition to disruption atau gangguan semakin besar dan terdapat dampak yang dirasakan, terletak pada story 11 hingga story 15 atau di menit 31.35 hingga 48.59 . Pada story ke sebelas ketika Butet yang telah mendapatkan izin dari Tumenggung untuk mengajar, ternyata ia mendapatkan penolakan dari beberapa anggota rombong yang percaya bahwa pensil atau kegiatan yang dilakukan oleh Butet dapat membawa penyakit. Beberapa anggota rombong menatap Butet dengan pandangan yang tidak menyenangkan. Selain itu, ibu Bungo juga menyindir Butet atas kegiatan belajarnya yang tidak sesuai dengan peraturan adat. Walaupun mendapat perlakuan seperti itu, Butet tetap melakukan kegiatan mengajar kepada anak - anak dan semakin banyak yang berminat untuk belajar bersamanya. Dari seluruh anak - anak di rombong tersebut, Bungo lah yang paling semangat untuk belajar. Dibalik semua itu, Butet menyadari sesuatu yang sangat berbahaya ketika kelompok pembalak liar datang dan berbincang dengan Tumenggung Belaman Badai. Butet melihat salah satu orang dari kelompok pembalak liar tersebut dan teringat dengan sosok yang mengejarnya dan hampir menembaknya ketika dalam perjalanan ke Hilir. Flashback yang ada pada menit 35.09 ini merupakan adegan yang ada di menit ke 21.36. Walaupun mundur ke belakang, interupsi ini tidak terlalu memberikan efek yang signifikan karena teknik kilas balik ini tidak mengganggu 
alur cerita secara keseluruhan. Bungo yang melihat kelompok tersebut, langsung menunjukkan gulungan kertas yang selama ini ia bawa kemana - mana kepada Butet. Gulungan kertas tersebut adalah surat perjanjian pengambilan kayu di wilayah adat mereka. Mereka menyetujuinya dengan memberikan cap jempol di atas surat yang tidak dapat mereka baca. Inilah yang menyebabkan Bungo ingin sekali dapat membaca isi surat tersebut. Mereka harus berpindah - pindah tempat karena perkebunan sawit semakin mendesak ke dalam dan adanya peraturan - peraturan dari Taman Nasional yang bertolak belakang dengan adat dan gaya hidup mereka, seperti berburu dan membuka ladang. Mereka terjebak dalam kebingungan, antara rasa curiga dan ketidakmampuan menahan desakan dari dunia luar.

Gangguan semakin besar lagi ketika ibu Bungo marah kepada bapak Bungo yang terjadi pada story ke dua belas atau menit 36.45 hingga 38.33. Beliau ingin Butet pergi dari wilayah mereka karena hal yang dilakukan oleh Butet dapat membawa penyakit. Bapak Bungo menjelaskan bahwa hal tersebut memiliki tujuan yang baik, namun ibu Bungo bersikeras untuk tidak ada kegiatan belajar mengajar di rombongnya. Ini membuat Tumenggung bingung dan akhirnya harus mengusir Butet secara halus dari rombongnya pada story ke 14 atau di menit 39.15 hingga 42.52. Butet yang di usir ketika Bungo dan kawan - kawannya sedang berburu, membuat Bungo marah ketika mengetahuinya. Ia membutuhkan Butet agar dapat belajar dan tidak dibodoh - bodohi oleh orang luar. Ia marah dan sempat mengajar Butet. Namun, usahanya tidak berhasil dan Butet harus pergi meninggalkannya. Dapat dilihat bahwa beberapa anggota rombong tidak dapat menerima kegiatan dari orang di luar anggota mereka. Namun, beberapa anggota rombong dapat menerima hal (belajar) tersebut. Disisi lain pada story ke tiga belas dalam menit 38.34 hingga 39.14, Bahar telah mengetahui bahwa Butet pergi lebih lama tanpa izin darinya.

Gangguan juga menjadi besar ketika Butet telah kembali ke kantor pada story ke lima belas atau dalam menit 45.11 hingga 48.59 . Perseteruan terjadi antara Butet dan Bahar. Butet yang merasa Bahar tidak peduli dengan orang - orang rimba membuat Bahar emosi dan mengamuk. Bahar merasa tugasnya dalam organisasi, menjaga luasan Taman Nasional, sudah sesuai. Namun, berbeda dengan sudut pandang Butet. Ia merasa masih banyak orang orang rimba yang masih kesulitan dalam menghadapi perubahan yang ada di wilayah mereka. Selain itu, permasalahan Bungo yang ingin belajar karena rombongnya sering ditipu oleh orang luar membuat Butet dianggap meracau oleh Bahar.

Pada tahap attempt to repair the disruption, hadir sosok pahlawan yang berupaya untuk memperbaiki kondisi. Usaha untuk mencapai keseimbangan kembali terlihat pada story 16 hingga story 23 atau dalam menit 49.00 hingga 01.23.17. Pada story ke enam belas, Butet mencari cara agar Bungo tetap dapat belajar. Ia mendapatkan cara agar Bungo bisa belajar dengan mengajar di rumah bu Pariyan, salah satu transmigran yang berasal dari Jawa 
PADA FILM SOKOLA RIMBA

Tengah. Rumah ibu Pariyan berada tepat di perbatasan antara hulu dan hilir sehingga jarak yang ditempuh dari hulu atau hilir tidak begitu jauh. Upaya yang dilakukan Butet berhasil. Pada story ke tujuh belas, Bungo yang mengetahui keberadaan Butet datang ke rumah ibu Pariyan dan akhirnya ia bisa belajar. Bungo tetap berusaha untuk dapat belajar walaupun ia harus melanggar kepercayaan rombongnya mengenai pensil (belajar) yang dapat membawa penyakit. Semakin lama anak - anak yang diajar oleh Butet semakin cerdas dan pintar, bahkan pada story ke sembilan belas Bungo sudah mencoba membaca isi surat perjanjian bersama Butet.

Tetapi, upaya untuk memperbaiki keadaan yang dilakukan oleh Butet tidak berjalan dengan lancar. Upaya yang dilakukan untuk memperbaiki keadaan yang terganggu tersebut justru mengalami gangguan yang menyebabkan munculnya kembali kekacauan. Gangguan tersebut terjadi pada story ke dua puluh ketika tiga orang anggota rombong Tumenggung Belaman Badai datang karena diutus oleh orang tua Bungo untuk membawa Bungo pulang. Ketiga orang ini memberikan kabar bahwa Tumenggung telah meninggal dunia. Ini mengagetkan Bungo dan Butet. Mereka menganggap penyebab dari kematian Tumenggung adalah akibat menerima ilmu yang diberikan oleh Butet. Situasi yang sebelumnya hampir mencapai keseimbangan kembali menjadi terganggu. Bungo sedih dan sempat berpikir hingga akhirnya ia memutuskan untuk kembali pulang ke rombongnya. Pada story ke 21, Bungo berusaha mengejar rombongnya yang melakukan tradisi adat, yaitu melangun. Melangun merupakan kegiatan berjalan jauh dengan waktu yang cukup lama sampai rasa duka yang dirasakan oleh rombong hilang. Melangun kali ini menjadi titik balik bagi Butet.

Pada story ke 22 ketika Butet kembali ke Bangko, muncul klimaks kekacauan yang memberikan dampak pada Butet. Bahar menugaskan Butet untuk menemani para wartawan meliput kegiatan belajar anak - anak rimba. Namun Butet menolak karena merasa hal tersebut hanyalah pencitraan bagi lembaga. Penolakan Butet membuat ia harus dipecat oleh Bahar karena tidak dapat mengikuti cara kerja mereka. Butet akhirnya pulang ke Jakarta.

Ketika di Jakarta, Butet menemukan cara agar dapat kembali ke rimba untuk memberikan pendidikan yang sesuai dengan kebutuhan mereka. Dalam story 23 atau menit ke 01.18.55 hingga 01.23.17, Butet mengisi seminar - seminar di perguruan tinggi untuk memperkenalkan orang rimba dan permasalahannya. Selain itu, ia bekerja sama dengan Andit dan dr. Astrid mencari pendonor untuk membangun sekolah sendiri. Sekolah tersebut dinamakan Sokola Rimba, sekolah ketahanan hidup yang tidak hanya mengajarkan baca, tulis, hitung, namun juga advokasi terhadap pelayanan dan hak mereka.

Pada tahap reinstatement of the equilibrium yang merupakan tahap akhir dimana kekacauan atau gangguan yang terjadi pada tahap sebelumnya telah berhasil 
ProTVF, Volume 2, Nomor 1, Maret 2018, Hal. 51-67

diselesaikan dan keseimbangan muncul kembali, terjadi pada story 24 atau menit 01.23.18 hingga 01.27.15, usaha yang dilakukan oleh Butet membuahkan hasil. Ia kembali ke rimba untuk membangun Sokola Rimba bersama teman - temannya yang ikut mendukung dirinya. Saat masuk ke hutan, mereka melihat Bungo dan rombongnya sedang bertemu dengan kelompok kepentingan perkebunan yang akan menipu mereka dengan surat perjanjian. Bungo yang ikut berhadapan dengan pihak perkebunan membaca surat perjanjian tersebut dan berdiskusi tentang poin - poin yang disetujui dan tidak disetujui.

Usaha Butet untuk memberikan pedidikan kepada Bungo dan semangat Bungo itu sendiri berhasil membawa dirinya berani mengahadapi perubahan yang terjadi kepada komunitasnya. Walaupun Bungo tidak ingin melepaskan diri dari komunitasnya. Bungo memiliki dorongan untuk bisa mengerti apa yang di inginkan orang luar dari tempat tinggalnya dan melakukan hal yang tepat untuk menghadapi perubahan. Menghadapi perubahan dengan senjata pengetahuan untuk bisa beradaptasi. Situasi kembali normal dan Rombong Bungo dapat menghadapi perubahan yang terjadi, mereka dapat menghadapi hal - hal yang bertentangan dengan adat mereka. Selain itu, Butet bersama teman - temannya mulai membangun saung atau pondok untuk Sokola Rimba dengan dibantu oleh anak - anak rimba.

Kondisi normal yang tercipta, berbeda dengan kondisi normal pada tahap pertama. Kondisi normal pada tahap ini ialah Butet yang berhasil membangun sekolah yang sesuai dengan kebutuhan anak - anak rimba dan Bungo serta orang - orang rimba lainnya bisa menerima dan mendapatkan pedidikan dan beradaptasi dengan perubahan sosial yang terjadi tanpa meninggalkan komunitasnya.

Berdasarkan pembahasan di atas, film Sokola Rimba memiliki pengulangan situasi pada tahap disruption, recognition disruption, dan attempt to repair the disruption. Pengulangan ini dilakukan untuk tujuan dramatis yang sudah melalui proses penyesuaian terhadap alur cerita itu sendiri. Hal ini dijelaskan juga oleh Riri Riza bahwa hampir semua peristiwan didasarkan pada bacaannya dalam buku Sokola Rimba yang ditulis Butet. Buku tersebut juga mengalami 'penyesuaian' untuk tujuan menjadi bacaan yang lebih populer. Beberapa bagian yang Riri Riza pilih untuk diceritakan juga melalui proses seleksi yang didasarkan pada keinginan bercerita secara jelas dan dramatis (Wawancara Online, 5 April 2017). Pengulangan tersebut dapat dilihat melalui grafik berikut ini :

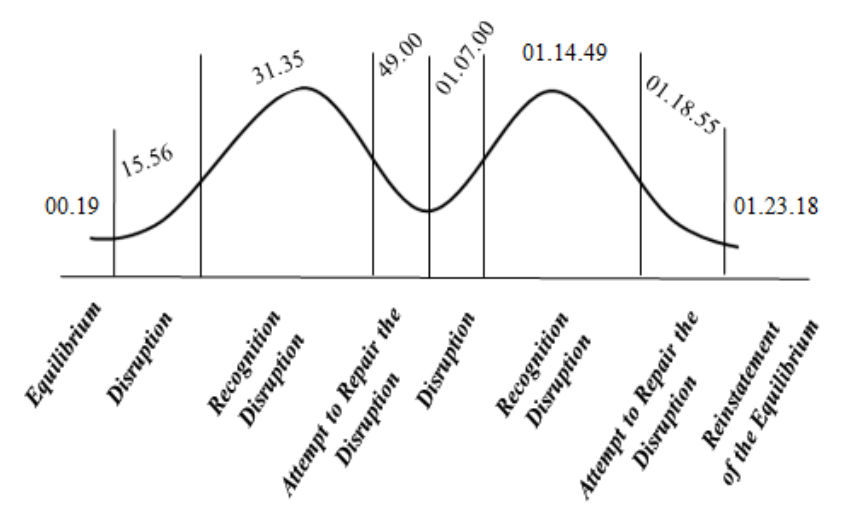

Sumber: Olahan Peneliti, 2017

Gambar 2 Grafik Alur Film Sokola Rimba 


\section{SIMPULAN}

Berdasarkan analisis naratif yang dilakukan untuk mengetahui struktur narasi yang ada, equilibrium terjadi di menit 00.19 hingga 15.55 atau story 1 hingga story 6 . Situasi yang terjadi normal tanpa ada gangguan yang dapat merusak keseimbangan. Walaupun terdapat beberapa bagian dari equilibrium yang menegangkan pada story 1 dan 3 , secara keseluruhan tidak ada tindakan yang merusak keseimbangan yang ada dan semua berjalan teratur. Disruption terjadi di menit 15.56 hingga 31.34 atau pada story 7 hingga story 10 dan berulang pada menit ke 01.07.00 atau pada story 20 hingga 21. Pada tahap ini, muncul gangguan terhadap keseimbangan yang ada. Gangguan pertama terjadi ketika Butet nekat untuk pergi ke Hilir tanpa izin dari Bahar dan melarikan diri dari kejaran pembalak liar saat perjalanan menuju Hilir. Gangguan kedua terjadi saat Bungo dan Butet mendapatkan kabar meninggalnya Tumenggung Belaman Badai dan Bungo memutuskan untuk kembali bersama rombongnya.

Recognize of Disruption terjadi di menit 31.35 hingga 48.59 atau pada story 11 hingga story 15 dan berulang pada menit ke 01.14.49 atau pada story 22. Pada tahap ini, gangguan mencapai titik puncak atau semakin besar dan muncul dampak yang dapat dirasakan, yaitu ketika Butet menyadari alasan Bungo yang ingin dapat belajar serta kebingungan rombongnya dalam menghadapi orang luar atau pihak perkebunan, Butet diusir dari rombong Tumenggung Belaman Badai karena kegiatan belajar yang diberikan melanggar adat, serta Bahar yang tidak setuju dengan sikap Butet yang terlalu mementingkan Bungo daripada organisasi. Gangguan menjadi klimaks lagi ketika akhirnya Butet dipecat oleh Bahar karena tidak bisa mengikuti cara kerja lembaga. Attempt to Repair the Disruption terjadi di menit 49.00 hingga 01.06 .59 atau pada story 16 hingga story ke 19 dan berulang pada menit ke 01.18.55 atau pada story ke 23. Pada tahap ini, hadir sosok pahlawan yang berupaya untuk memperbaiki keadaan agar kembali mencapai keseimbangan. Sosok pahlawan disini adalah Butet yang memutuskan untuk mengajar di rumah ibu Pariyan agar Bungo dapat tetap belajar walaupun dianggap melanggar kepercayaan adat. Butet yang kembali ke Jakarta karena di pecat kembali melakukan usaha agar ia dapat kembali ke rimba dengan menjadi pembicara di seminar perguruan tinggi dan bertemu dengan pendonor untuk dapat membangun sekolah sendiri yang bernama Sokola Rimba. Reinstatement of Equilibrium terjadi di menit 01.23.18 hingga 01.27.15 atau pada story ke 24. Pada tahap ini, gangguan atau kekacauan yang telah terjadi berhasil diselesaikan dan kembali muncul keseimbangan. Keseimbangan ini berbeda dengan keseimbangan yang ada pada tahap awal. Seluruh gangguan yang terjadi baik dari orang rimba dan Butet sendiri terselesaikan pada tahap ini. Secara keseluruhan, dapat disimpulkan bahwa film Sokola Rimba ini menggunakan alur yang lebih modern dan tidak terpaku dengan alur tradisional yang dijabarkan 
oleh Tzvetan Todorov. Selain itu, unsur mise en scene mendukung naratif yang ada dalam membangun suasana pada film.

Adapun saran yang dapat peneliti berikan setelah melakukan penelitian ini, yaitu pertama untuk peneliti selanjutnya dapat mengembangkan penelitian mengenai struktur naratif Tzvetan Todorov lebih dalam lagi dan dapat menambah referensi mengenai naratif Tzvetan Todorov. Selain itu, peneliti selanjutnya sebaiknya lebih mengembangkan penelitian yang menggunakan analisis naratif dengan teori yang lain untuk membandingkan dengan alur Todorov. Seperti memakai teori dari Vladimir Propp, Levi-Strauss, dan juga Algirdas Greimas Model Aktan ataupun Oposisi Segi Empat.

\section{DAFTAR PUSTAKA}

Eriyanto. 2013. Analisis Naratif: Dasar-dasar dan Penerapannya dalam

Analisis Teks Berita Media. Jakarta: Kencana Prenada Media Group

Film Indonesia. 2013. Data Penonton. Diakses pada http://filmindonesia.or.id/pada tanggal 10 Mei 2017 pukul 09.56 WIB.

Ghony, Djunaidi \& Almanshur, Fauzan. 2012. Metode Penelitian Kualitatif. Yogyakarta: Ar-Ruzz Media.
Heryadi, Hedi dan Hana Silvana. 2013. Komunikasi Antarbudaya Dalam

Masyarakat Multikultur. Jurnal Kajian Komunikasi (JKK), Vol.1, No.1, pp. 97108. doi: 10.24198/jkk.vli1.6034

Jusuf, Windu. 2017. Riset Mandiri Tirto:

Kebanyakan Penonton Tak Puas dengan

Film Adaptasi Novel. Diakses dari https://tirto.id/kebanyakan-penonton-takpuas-dengan-film-adaptasi-novel-clW9 pada tanggal 9 Mei 2017 pukul 14.05 WIB.

Miles Films. 2013. Sokola Rimba. Diakses dari http://milesfilms.net/sokola-rimba/pada tanggal 20 September 2016 pukul 15.42 WIB

Saputra, Heru S.P. 2009. Humaniora, Vol.21, No.1, pp. 41-55.

Pratista, Himawan. 2008. Memahami Film. Yogyakarta: Homerian Pustaka.

Sugiyono. 2016. Metode Penelitian Kuantitatif, Kualitatif, dan R\&D. Bandung: Alfabeta. Yasundari. 2016. Hubungan Antara Penggunaan Media Sosial Instagram dengan Motivasi Wirausaha Pebisnis Daring (online) dalam Meningkatkan Produktivitas. Jurnal Kajian Komunikasi (JKK), Vol.4, No.2, pp. 208-218. doi: 10.24198/jkk.v4i2.7737 